\title{
PHD Defence: “Now Playing, You: Big Data and the Production of Music Streaming Space" by Robert Prey
}

\author{
Vu Thuy Anh Phan \\ School of Communication \\ Simon Fraser University
}

Our dear colleague, Robert Prey, will defend his PhD dissertation on Tuesday, November $3^{\text {rd, }} 2015$ at Harbour Centre, Room 1520 (10:30 am -1:30 pm). Here is the abstract of his dissertation "Now Playing, You: Big Data and the Production of Music Streaming Space"

\begin{abstract}
This dissertation begins from the premise that Dallas Smythe's attempt to develop a Marxist 'materialist' political economy of media remains a critically important - and unfinished - project. To-date, the debate has largely been concerned with locating the central commodity produced by adsupported media. This commodity has been at various times identified as either 'audiences', 'watching-time', 'ratings', and more recently, 'prosumers' or 'data'.

Building from the late philosopher Henri Lefebvre's insight that Marxists have too often focused on the production of commodities in capitalist space, leaving them blind to the production of capitalist space itself, this dissertation proposes a different approach. Ad- supported media, I argue, generate rents from the spaces that are produced by media audiences/users around media content. The question of how 'media space' is produced and shaped by the stipulations of rent extraction is examined through a case study of the ad- supported music streaming sector. From terrestrial radio to P2P file sharing, music has long facilitated the production of mediated "social space". Contemporary music streaming services such as Spotify, SoundCloud and Pandora Internet Radio, represent the latest attempt to transform the spaces of listeners into spaces of capital: what Lefebvre referred to as "abstract space".

This dissertation investigates the perceived, conceived, and lived dimensions of the struggle to produce abstract space on music streaming platforms. In particular, the role played by data mining and analysis, as typified by the music intelligence company The Echo Nest, is examined. I argue that the drive to increase advertising revenues leads to the further segmentation and ordering of listeners and content, as sociability is turned upon itself to fulfill the dictates of capital. While social space is never entirely dissolved, abstract space increasingly shapes the potentialities of social space, as our examination of SoundCloud demonstrates.

In short, this dissertation develops an alternative materialist political economy of media that shifts focus from the production of commodities to the production of spaces. Music streaming services provide a window into the dynamic and unstable process through which mediated social space is made abstract in the commercial media economy.
\end{abstract}

Keywords: political economy of communication, audience commodity, streaming music, Henri Lefebvre 